\title{
Do herbivorous minnows have "plug-flow reactor" guts? Evidence from digestive enzyme activities, gastrointestinal fermentation, and luminal nutrient concentrations
}

\author{
Donovan P. German
}

Received: 23 September 2008 / Revised: 24 March 2009 / Accepted: 25 March 2009 / Published online: 11 April 2009

(C) The Author(s) 2009. This article is published with open access at Springerlink.com

\begin{abstract}
Few investigations have empirically analyzed fish gut function in the context of chemical reactor models. In this study, digestive enzyme activities, levels of gastrointestinal fermentation products [short chain fatty acids (SCFA)], luminal nutrient concentrations, and the mass of gut contents were measured along the digestive tract in herbivorous and carnivorous minnows to ascertain whether their guts function as "plug-flow reactors" (PFRs). Four of the species, Campostoma anomalum, C. ornatum, C. oligolepis, and C. pauciradii, are members of a monophyletic herbivorous clade, whereas the fifth species, Nocomis micropogon, is a carnivore from an adjacent carnivorous clade. In the context of a PFR model, the activities of amylase, trypsin and lipase, and the concentrations of glucose, protein, and lipid were predicted to decrease moving from the proximal to the distal intestine. I found support for this as these enzyme activities and nutrient concentrations generally decreased moving distally along the intestine of the four Campostoma species. Furthermore, gut content mass and the low SCFA concentrations did not change (increase or decrease) along the gut of any species. Combined with a previous investigation suggesting that species of Campostoma have rapid gut throughput rates, the data presented
\end{abstract}

Communicated by I.D. Hume.

\section{P. German}

Department of Zoology, University of Florida,

Gainesville, FL, USA

Present Address:

D. P. German $(\square)$

Department of Ecology and Evolutionary Biology,

University of California, Irvine, CA 92697, USA

e-mail: dgerman@uci.edu here generally support Campostoma as having guts that function as PFRs. The carnivorous N. micropogon showed some differences in the measured parameters, which were interpreted in the contexts of intake and retention time to suggest that PFR function breaks down in this carnivorous species.

Keywords Digestion - Digestive physiology $\cdot$ Nutritional ecology $\cdot$ Chemical reactor models $\cdot$ Microbial

\section{Introduction}

The mechanisms of food ingestion and digestion influence nearly all aspects of an animal's behavior and physiology (Karasov and Martínez del Rio 2007). In turn, an animal's foraging strategy-whether it is a predator consuming high-quality foods on an intermittent basis, or an herbivore continuously digesting low-quality food-will affect the structure and function of their digestive tract. Gut structure and function appear to match dietary intake and quality, theoretically (Sibly and Calow 1986; Jumars 2000; Whelan et al. 2000), and empirically in a range of vertebrate taxa (Stevens and Hume 1995; Karasov and Martínez del Rio 2007). However, the diversity of gut morphologies and diets in fishes has made it difficult to apply theoretical considerations to fish gut function.

Horn and Messer (1992) modeled herbivorous fish guts as chemical reactors, ultimately arriving at the conclusion that gut morphology (especially length) and food passage rate can best describe how a fish gut functions in relation to diet quality. Under these models, herbivorous fishes are expected to have longer digestive tracts and longer retention of food in the gut than their carnivorous counterparts. However, several researchers have shown that simple gut 
morphology fails to adequately describe gut function in herbivorous fishes. For example, Atherinops affinis has a short, stomachless digestive tract and passes algae through its gut in $2 \mathrm{~h}$ (Logothetis et al. 2001). Conversely, Odax pullus and $O$. cyanomelas (family Labridae), which also have relatively short, anatomically unspecialized digestive tracts with no stomach, caeca, or valves of any kind, hold algae in their guts for nearly $20 \mathrm{~h}$ (Clements and Rees 1998) and harbor an endosymbiont community capable of fermenting indigestible algal compounds (e.g., mannitol; Seeto et al. 1996; Mountfort et al. 2002).

A more reasonable approach to understanding fish digestion can be followed by taking into account rates of reaction (e.g., digestive enzyme activities) and nutrient concentrations along the digestive tract (Crossman et al. 2005; Skea et al. 2005, 2007). Horn and Messer (1992) predicted that herbivorous fishes with "plug-flow reactor" (PFR) digestive tracts-those with unspecialized intestinal morphology (no kinks, valves, or caeca), and digesta that moves in a unidirectional trajectory down the intestine with no axial mixing (Penry and Jumars 1987; Jumars 2000)—should have high intake, and relatively short retention times of digesta in the alimentary canal. Thus, these fishes would rely almost entirely on endogenous digestive mechanisms and would have low levels of endosymbiont fermentation [i.e., low short chain fatty acid (SCFA) concentrations] in their guts. PFR guts, they predicted, should have steep gradients of nutrient concentration and digestive enzyme activities along the intestine, with both more concentrated in the foregut, and most of the absorption of nutrients taking place in the mid to distal intestine (Horn and Messer 1992; Jumars 2000).

Minnows in the genus Campostoma (family Cyprinidae, comprising minnows and carps) are small $(<25 \mathrm{~g})$, wellstudied algal grazers in North American freshwater ecosystems. Although Campostoma have been investigated in terms of their effects on algal community dynamics (Power et al. 1988; Gelwick and Matthews 1997) and ecosystem health (Power et al. 1985; Gelwick and Matthews 1992; Evans-White et al. 2003), little is known about the structure and function of their alimentary tract. Generally, cyprinids are characterized as having long, thin-walled digestive tracts that lack a gastric stomach (Kraatz 1924; German et al. 2009), and they are known to possess pharyngeal teeth (German et al. 2009) with which they grind and crush (Evans and Deubler 1955; Cloe et al. 1995) foods into smaller, more digestible (Xie 1999, 2001) particles. With a pharyngeal grinding apparatus followed by what seems to be an anatomically unspecialized intestine, cyprinids appear to possess a PFR digestive tract as described by Horn and Messer (1992). Functional support for this comes from observations that Campostoma have rapid gut transit times ( $<8 \mathrm{~h}$ total gut clearance) and do not hold food in the gut overnight (Fowler and Taber 1985). However, what is clearly missing is an evaluation of digestive enzyme activities, gastrointestinal fermentation, and luminal nutrient concentrations in digestive tracts of Campostoma in the context of chemical reactor models to address whether their guts function as PFRs.

In this study, I evaluated the function of the digestive tract in four species of Campostoma (C. anomalum, C. ornatum, C. oligolepis, and C. pauciradii), and in a closely related carnivore, Nocomis micropogon (German et al. 2009). I measured the activity levels of five digestive enzymes (amylase, maltase, trypsin, aminopeptidase, and lipase), luminal nutrient concentrations, the mass of gut contents, and levels of gastrointestinal fermentation along the digestive tract in the five minnow species to evaluate whether their gut functions as a PFR. If these minnow taxa possess a PFR gut, then nutrient concentrations and the activities of amylase, trypsin and lipase should decline distally in the digestive tract. Maltase and aminopeptidase activities might be expected to increase distally in the intestine (Fraisse et al. 1981; Harpaz and Uni 1999), as these enzymes hydrolyze maltose and dipeptides, respectively, just preceding absorption; a PFR model predicts that absorption will preferentially take place in the mid- to distal intestine (Horn and Messer 1992; Jumars 2000). Under the PFR model, digesta content mass (Parra 1978) and concentrations of fermentation end products (SCFAs) should not be localized to any one region of the alimentary canal, and SCFA concentrations should be low (Stevens and Hume 1998). Additionally, comparisons of the Campostoma taxa with $N$. micropogon may provide evidence of functional differences between herbivores and carnivores.

\section{Materials and methods}

Fish capture and tissue preparation

Fishes were captured by seine and a backpack electroshocker during the summer months (June-August) between 2004 and 2006 from streams throughout the eastern United States and northern Mexico (Table 1). Upon capture, fishes were placed in coolers of aerated stream water and held until euthanized $(<2 \mathrm{~h})$. Specimens were prepared following German et al. (2009). Briefly, fishes were euthanized in buffered water containing $1 \mathrm{~g} \mathrm{l}^{-1}$ tricaine methanesulfonate (MS-222, Argent Chemicals Laboratory, Inc., Redmond, WA, USA), measured [standard length $(\mathrm{SL}) \pm 1 \mathrm{~mm}$ ], weighed [body mass $(\mathrm{BM}) \pm 0.01 \mathrm{~g}$ ], and dissected on a chilled $\left(\sim 4^{\circ} \mathrm{C}\right)$ cutting board. Guts were removed by cutting at the esophagus and at the anus. The guts were then uncoiled, without stretching, and measured [gut length (GL) $\pm 1 \mathrm{~mm}$ ]. Because species of Campostoma and Nocomis have slightly different gut morphology and guts 
Table 1 Collection locations for five minnow taxa used in this study of digestive characters of the genera Campostoma and Nocomis

\begin{tabular}{|c|c|c|c|c|c|}
\hline Taxon $(N)$ & $\operatorname{Diet}^{\mathrm{b}}$ & Collection location & Drainage & Latitude & Longitude \\
\hline C. anomalum (10) & $\mathrm{H}$ & Flint Creek, Arkansas, USA & Arkansas River & $36^{\circ} 46.142^{\prime \prime} \mathrm{N}$ & $94^{\circ} 41.601 ” \mathrm{~W}$ \\
\hline C. ornatum (10) & $\mathrm{H}$ & Rìo Santa Isabel, Chihuahua, Mexico & Rìo Conchos & $28^{\circ} 32.463^{\prime \prime} \mathrm{N}$ & $106^{\circ} 30.218^{\prime \prime} \mathrm{W}$ \\
\hline C. oligolepis (10) & $\mathrm{H}$ & Wedowee Creek, Alabama, USA & Tallapoosa River & $33^{\circ} 18.496^{\prime \prime} \mathrm{N}$ & $85^{\circ} 26.068^{\prime \prime} \mathrm{W}$ \\
\hline C. pauciradii $i^{\mathrm{a}}(6)$ & $\mathrm{H}$ & Hillabahatchee Creek, Georgia, USA & Chattahoochee River & $33^{\circ} 18.632^{\prime \prime} \mathrm{N}$ & $85^{\circ} 11.288^{\prime} \mathrm{W}$ \\
\hline C. pauciradii ${ }^{\mathrm{a}}(5)$ & $\mathrm{H}$ & Candler Creek, Georgia, USA & Altamaha River & $34^{\circ} 18.697^{\prime \prime} \mathrm{N}$ & $83^{\circ} 39.441^{\prime} \mathrm{W}$ \\
\hline N. micropogon (6) & $\mathrm{C}$ & Shoal Creek, Alabama, USA & Tennessee River & $34^{\circ} 57.140^{\prime \prime} \mathrm{N}$ & $87^{\circ} 35.410^{\prime \prime} \mathrm{W}$ \\
\hline
\end{tabular}

${ }^{a}$ Because of dietary and morphological similarities, individuals from the two populations of $C$. pauciradii were pooled for all analyses

b " $\mathrm{H}$ " denotes herbivore, whereas " $\mathrm{C}$ " denotes carnivore

that differ in length, digestive tracts from the two genera were processed in slightly different ways. For the Campostoma species, the gut was divided into three equal sections representing the proximal intestine, mid intestine, and distal intestine. For N. micropogon, the gut was divided into two sections, the proximal intestine representing the proximal third of the intestine up to a small "bend" that is present in Nocomis taxa (German et al. 2009), and the remaining distal intestine. Guts were divided differently among the two genera because $N$. micropogon did not have enough gut tissue to further divide the intestine and allow for tissue homogenates to be made at a reasonable dilution. Once the guts were measured and divided, the gut contents were pushed out of the intestinal tissues with forceps and the blunt side of a razorblade, and into sterile centrifuge vials (Horn et al. 2006; German 2008; German et al. 2009). The evacuated intestinal tissues were then individually placed into sterile centrifuge vials. Both, the gut contents and the intestinal tissues were then frozen (in their vials) on dry ice, transported back to the University of Florida, and placed at $-80^{\circ} \mathrm{C}$ until analyzed.

Gut tissues from each gut region from individual fish were weighed (regional gut mass $\pm 0.001 \mathrm{~g}$ ) and homogenized in ice-cold $0.05 \mathrm{M}$ Tris- $\mathrm{HCl}$ buffer $\mathrm{pH} 7.4$ using a Polytron homogenizer (Brinkmann Instruments, Westbury, NY, USA) with a 7-mm generator at a setting of 2,200 rpm for $3 \times 30 \mathrm{~s}$ (German et al. 2004). Dilution varied between three and 60 volumes $(\mathrm{v} / \mathrm{w})$ depending on the mass of the gut region being homogenized. The homogenates were then centrifuged at $9,400 \times g$ for $2 \mathrm{~min}$ at $4^{\circ} \mathrm{C}$ and the supernatants collected and stored in small aliquots (100-200 $\mu \mathrm{l})$ at $-80^{\circ} \mathrm{C}$ until just before use in spectrophotometric assays of activities of the five digestive enzymes. Following centrifugation, the protein content of the homogenates was measured using bicinchoninic acid (Smith et al. 1985).

Assays of digestive enzyme activity

All assays were carried out at $25^{\circ} \mathrm{C}$ in triplicate using the Bio-Rad Benchmark Plus microplate spectrophotomer and
Falcon flat-bottom 96-well microplates (Fisher Scientific). All $\mathrm{pH}$ values listed for buffers were measured at room temperature $\left(22^{\circ} \mathrm{C}\right)$, and all reagents were purchased from Sigma-Aldrich Chemical (St Louis). All reactions were run at saturating substrate concentrations as determined for each enzyme with gut tissues from the five species (German et al. 2009). Each enzyme activity was measured in each gut region of each individual fish, and blanks consisting of substrate only and homogenate only (in buffer) were conducted simultaneously to account for endogenous substrate and/or product in the tissue homogenates and substrate solutions.

The $\alpha$-amylase (EC 3.2.1.1) activity was measured according to the Somogyi-Nelson method (Nelson 1944; Somogyi 1952), as described by German et al. (2004, 2009). Briefly, starch substrate was prepared by boiling $2 \%$ soluble starch in $0.8 \mathrm{M}$ sodium citrate buffer $(\mathrm{pH}$ 7.0) for $5 \mathrm{~min}$. In a microcentrifuge vial, $50 \mu \mathrm{l}$ of the starch solution was combined with $50 \mu$ of a mixture of sodium citrate buffer and gut tissue homogenate. Homogenate volumes ranged from 5 to $25 \mu$ depending on $\alpha$-amylase concentration in the homogenates. The incubation was stopped after $15-25 \mathrm{~min}$ by adding $20 \mu \mathrm{l}$ of $1 \mathrm{M} \mathrm{NaOH}$ and $200 \mu \mathrm{l}$ of Somogyi-Nelson reagent A. Somogyi-Nelson reagent B was added after the assay solution was boiled for $10 \mathrm{~min}$ (see German et al. 2004 for reagent recipes). The resulting solution was diluted in deionized water and centrifuged at $6,000 \times g$ for $5 \mathrm{~min}$. The glucose content of the solution was then determined spectrophotometrically at $650 \mathrm{~nm}$. The $\alpha$-amylase activity was determined from a glucose standard curve and expressed in $\mathrm{U}(1 \mu \mathrm{mol}$ glucose liberated per minute) per gram wet weight of gut tissue.

Maltase (3.2.1.20) activity was measured following Dahlqvist (1968) as described by German et al. (2004). In a microcentrifuge tube, $10 \mu \mathrm{l}$ of $56 \mathrm{mM}$ maltose dissolved in $100 \mathrm{mM}$ maleate buffer, $\mathrm{pH} 7.0$, was combined with $10 \mu \mathrm{l}$ of diluted regional gut homogenate. After $10 \mathrm{~min}$, the reaction was stopped by the addition of $300 \mu \mathrm{l}$ of assay reagent (Sigma GAGO20) dissolved in $1 \mathrm{M}$ Tris-HCl, $\mathrm{pH}$ 7.0. The reaction mixture was incubated for $30 \mathrm{~min}$ at $37^{\circ} \mathrm{C}$, and was 
stopped by the addition of $300 \mu \mathrm{l}$ of $12 \mathrm{~N} \mathrm{H}_{2} \mathrm{SO}_{4}$. The amount of glucose in the solution was then determined spectrophotometrically at $540 \mathrm{~nm}$. The maltase activity was determined from a glucose standard curve and expressed in $\mathrm{U}$ ( $1 \mu \mathrm{mol}$ glucose liberated per minute) per gram wet weight of gut tissue.

Trypsin (E.C. 3.4.21.4) activity was assayed using a modified version of the method designed by Erlanger et al. (1961) as described by Gawlicka et al. (2000). The substrate, $2 \mathrm{mM} \mathrm{N} \alpha$-benzoyl-L-arginine- $p$-nitroanilide hydrochloride (BAPNA), was dissolved in $100 \mathrm{mM}$ Tris- $\mathrm{HCl}$ buffer ( $\mathrm{pH}$ 8.0) by heating to $95^{\circ} \mathrm{C}$ (Preiser et al. 1975; German et al. 2004). In a microplate, $95 \mu 1$ of BAPNA was combined with $5 \mu \mathrm{l}$ of homogenate, and the increase in absorbance was read continuously at $410 \mathrm{~nm}$ for $15 \mathrm{~min}$. Trypsin activity was determined with a $p$-nitroaniline standard curve, and expressed in $\mathrm{U}(1 \mu \mathrm{mol} p$-nitroaniline liberated per minute) per gram wet weight of gut tissue.

Aminopeptidase (EC 3.4.11.2) activity was measured according to Roncari and Zuber (1969) as described by German et al. (2004). In a microplate, $90 \mu \mathrm{l}$ of $2.04 \mathrm{mM}$ L-alanine- $p$-nitroanilide $\mathrm{HCl}$ dissolved in $200 \mathrm{mM}$ sodium phosphate buffer ( $\mathrm{pH}$ 7.0) was combined with $10 \mu \mathrm{l}$ of homogenate. The increase in absorbance was read continuously at $410 \mathrm{~nm}$ for $15 \mathrm{~min}$ and activity determined with a $p$-nitroaniline standard curve. Aminopeptidase activity was expressed in $\mathrm{U}(1 \mu \mathrm{mol} p$-nitroaniline liberated per minute) per gram wet weight of gut tissue.

Lipase (nonspecific bile-salt activated E.C. 3.1.1.-) activity was assayed using a modified version of the method designed by Iijima et al. (1998). In a microplate, $86 \mu \mathrm{l}$ of $5.2 \mathrm{mM}$ sodium cholate dissolved in $250 \mathrm{mM}$ Tris$\mathrm{HCl}(\mathrm{pH} 9.0)$ was combined with $6 \mu \mathrm{l}$ of homogenate and $2.5 \mu \mathrm{l}$ of $10 \mathrm{mM} 2$-methoxyethanol and incubated at room temperature for $15 \mathrm{~min}$ to allow for lipase activation by bile salts. The substrate $p$-nitrophenyl myristate $(5.5 \mu \mathrm{l}$ of $20 \mathrm{mM} p$-nitrophenyl myristate dissolved in 100\% ethanol) was then added and the increase in absorbance was read continuously at $405 \mathrm{~nm}$ for $15 \mathrm{~min}$. Lipase activity was determined with a $p$-nitrophenol standard curve, and expressed in $\mathrm{U}(1 \mu \mathrm{mol} p$-nitrophenol liberated per minute) per gram wet weight of gut tissue.

The activity of each enzyme was regressed against the protein content of the homogenates to confirm that there were no significant correlations between the two variables. Because no significant correlations were observed, the data are not reported as $\mathrm{U}$ per $\mathrm{mg}$ protein.

Gut fluid preparation, gastrointestinal fermentation, and luminal nutrient concentrations

Measurements of symbiotic fermentation activity were based on the methods of Pryor and Bjorndal (2005).
Fermentation activity was indicated by relative concentrations of SCFA in the fluid contents of the guts of the fishes at the time of death. Gut content samples were weighed [gut content mass $(\mathrm{GCM} \pm 0.001 \mathrm{~g})$ ], thawed, homogenized with a vortex mixer, and centrifuged under refrigeration $\left(4^{\circ} \mathrm{C}\right)$ at $16,000 \mathrm{~g}$ for $10 \mathrm{~min}$. The supernatant was then pipetted into a sterile centrifuge vial equipped with a $0.22 \mu \mathrm{m}$ cellulose acetate filter (Costar Spin-X gamma sterilized centrifuge tube filters, Coming, NY, USA) and centrifuged under refrigeration at $13,000 \times g$ for $15 \mathrm{~min}$ to remove particles from the fluid (including bacterial cells). The filtrates were collected and frozen until they were analyzed for SCFA and nutrient concentrations.

Concentrations of SCFA in the gut fluid samples from each gut region were measured using gas chromatography. Samples were hand-injected into a Shimadzu GC-9AM gas chromatograph equipped with a flame ionization detector (Shimadzu Scientific Instruments, Inc., Columbia, MD, USA) and a Perkin Elmer LC-100 integrator (Perkin Elmer, Inc., CT, USA). Two $\mu$ l of each sample were injected onto a 2-m long glass column (3.2 mm ID) packed with $10 \%$ SP-1000 and $1 \% \mathrm{H}_{3} \mathrm{PO}_{4}$ on 100/120 Chromosorb W AW (Supelco, Inc., Bellefonte, PA). Carrier gas was $\mathrm{N}_{2}$, at a flow rate of $40 \mathrm{ml} \mathrm{min}^{-1}$. Temperatures of the inlet, column, and detector were 180,155 , and $200^{\circ} \mathrm{C}$, respectively. An external standard containing $100 \mathrm{mg}^{-1}$ each of acetate, propionate, isobutyrate, butyrate, isovalerate, and valerate was used for calibration. The SCFA concentrations are expressed as mmol $1^{-1}$ of gut fluid, and are also presented as ratios of the percent of acetate, propionate, and butyrate in the samples, as is commonly practiced in studies of fermentation in domestic (Bergman 1990), and wild animals (Bouchard and Bjorndal 2005; Pryor and Bjorndal 2005; Pryor et al. 2006). Because of their small size, the gut contents of $C$. ornatum were pooled into one sample for each fish, and therefore, regional estimates of fermentation (and luminal nutrient concentrations) along the digestive tract were not possible.

Nutrient concentrations in the gut fluid were carried out to examine how the concentrations of glucose, protein, and lipid varied along the gut. Glucose concentrations were analyzed in 1-5 $\mu \mathrm{l}$ of gut fluid using the same glucose content assay described for the maltase assay above. The only departure being that there was no pre-incubation with maltose; the gut fluid was immediately combined with the assay reagent and incubated at $37 \mathrm{C}$ for $30 \mathrm{~min}$, the reaction stopped with $12 \mathrm{~N} \mathrm{H}_{2} \mathrm{SO}_{4}$, and the resulting mixture read in a spectrophotometer at $540 \mathrm{~nm}$ against a glucose standard curve.

Protein was measured with bicinchoninic acid (Smith et al. 1985) following the protocol of the BCA protein assay kit (Pierce, Rockford, IL, USA). In a microplate, 
$10 \mu \mathrm{l}$ of diluted gut fluid was combined with $200 \mu \mathrm{l}$ of BCA reagent and incubated at $37^{\circ} \mathrm{C}$ for $30 \mathrm{~min}$. The plate was then read in a spectrophotometer at $562 \mathrm{~nm}$, and the protein content determined from a standard curve made with bovine serum albumin. We recognize that this method determines total protein concentration, including free aromatic amino acids, peptides, and complete proteins. Therefore, digestive enzymes of endogenous and exogenous origin likely contributed to the protein concentrations in the gut fluid. More precise examination of different amino acid groups can provide more detail in terms of hydrolytic end products of digestive enzyme activity (Mayer et al. 1997; Crossman et al. 2005). However, I was interested in the relative pattern of protein concentration along the gut (Hofer 1982) so this "coarse" measurement was suitable to answer the question at hand.

Lipid content was assayed following the charring method of Marsh and Weinstein (1966). In a microcentrifuge vial, $10 \mu \mathrm{l}$ of intestinal fluid was combined with $50 \mu \mathrm{l}$ of $2: 1(\mathrm{v}: \mathrm{v})$ chloroform/methanol and vortexed at 30 -s intervals over $10 \mathrm{~min}$. Then, $12.5 \mu \mathrm{l}$ of $1 \mathrm{M} \mathrm{NaCl}$ (Neighbors and Horn 1991) was added and the mixture vortexed again for $1 \mathrm{~min}$. The mixture was then centrifuged at $6,200 \times g$ for $2 \mathrm{~min}$, and 5-10 $\mu \mathrm{l}$ of the bottom phase was pipetted into a glass vial. To evaporate the solvent, the vial was then baked at $60^{\circ} \mathrm{C}$ for $30 \mathrm{~min}$. To the glass vial, I then added $200 \mu \mathrm{l}$ of concentrated $(36 \mathrm{M}) \mathrm{H}_{2} \mathrm{SO}_{4}$ and baked the vial and its contents at $200^{\circ} \mathrm{C}$ for $15 \mathrm{~min}$. The vials were then allowed to cool in a water bath, after which $300 \mu$ of deionized water was added and $100 \mu \mathrm{l}$ of the resulting fluid was read in a spectrophotometer at $375 \mathrm{~nm}$. Lipid content was determined from a standard curve constructed with stearic acid.
Relative gut content mass

In terrestrial animals that utilize gastrointestinal fermentation to meet at least part of their daily energetic needs, nearly half the gut content mass at a given time is concentrated in a portion of the gut where fermentation actively takes place (Parra 1978; Pryor and Bjorndal 2005). Thus, in concert with my estimates of SCFA concentrations in each region of the gut, I examined the relative gut content mass [RGCM = GCM ( $\mathrm{g}) / \mathrm{BM}(\mathrm{g})]$ of each of the gut regions in the five species to determine whether gut contents are more concentrated in one portion of the gut over the other.

\section{Statistical analyses}

Prior to all significance tests, a Levene's test for equal variance was performed to ensure the appropriateness of the data for parametric analyses. If the data were not normal, they were log transformed, and normality confirmed prior to analysis. All tests were run using Minitab statistical software (version 13, State College, PA, USA). I was interested in the patterns of enzymatic activities, gastrointestinal fermentation, luminal nutrient concentrations, and gut content mass along the alimentary canal of each of the fish species. Thus, in the three species of Campostoma I used ANOVA, followed by a Tukey's HSD test with a family error rate of $P=0.05$, to examine how the enzyme activities, total SCFA concentrations, nutrient concentrations, and gut content mass varied among the proximal, mid, and distal intestines. I used $t$-tests to compare the same variables among the proximal and distal intestine in $N$. micropogon. ANOVA and $t$-test statistics are shown in Table 2, separately from the data, which are graphed in Fig. 1. Because I was unable to measure regional SCFA, nutrient concentration,

Table 2 Summary of ANOVA statistics for intraspecific comparisons of digestive enzyme activities among gut regions in five species of minnows

\begin{tabular}{|c|c|c|c|c|c|}
\hline Enzyme & C. anomalum & C. ornatum & C. oligolepis & C. pauciradii & N. micropogon \\
\hline \multirow[t]{2}{*}{ Amylase } & $F_{2,29}=8.06$ & $F_{2,29}=0.78$ & $F_{2,29}=9.87$ & $F_{2,32}=25.34$ & $t=0.19$ \\
\hline & $P<0.01$ & $P=0.47$ & $P<0.01$ & $P<0.01$ & $P=0.85$ \\
\hline \multirow[t]{2}{*}{ Maltase } & $F_{2,23}=0.51$ & $F_{2,17}=0.19$ & $F_{2,29}=94.42$ & $F_{2,29}=4.17$ & $t=1.04$ \\
\hline & $P=0.61$ & $P=0.83$ & $P<0.01$ & $P=0.03$ & $P=0.32$ \\
\hline \multirow[t]{2}{*}{ Trypsin } & $F_{2,29}=53.98$ & $F_{2,23}=1.09$ & $F_{2,29}=48.10$ & $F_{2,32}=16.83$ & $t=0.77$ \\
\hline & $P<0.01$ & $P=0.36$ & $P<0.01$ & $P<0.01$ & $P=0.46$ \\
\hline \multirow[t]{2}{*}{ Aminopeptidase } & $F_{2,23}=4.37$ & $F_{2,14}=4.35$ & $F_{2,29}=9.04$ & $F_{2,29}=5.55$ & $t=2.01$ \\
\hline & $P=0.03$ & $P=0.04$ & $P<0.01$ & $P=0.01$ & $P=0.07$ \\
\hline \multirow[t]{2}{*}{ Lipase } & $F_{2,29}=12.68$ & $F_{2,29}=9.92$ & $F_{2,29}=187.79$ & $F_{2,32}=42.51$ & $t=10.61$ \\
\hline & $P<0.01$ & $P<0.01$ & $P<0.01$ & $P<0.01$ & $P<0.01$ \\
\hline
\end{tabular}

Data are presented in Fig. 1. Sample sizes for each species and enzyme are as follows: $C$. anomalum, amylase $n=10$; maltase $n=8$; trypsin $n=10$; aminopeptidase $n=8$; lipase $n=10$. C. ornatum, amylase $n=10$; maltase $n=6$; trypsin $n=8$; aminopeptidase $n=5 ;$ lipase $n=10$. C. oligolepis, $n=10$ for all enzymes. C. pauciradii, amylase $n=11$; maltase $n=10$; trypsin $n=11$; aminopeptidase $n=10$; lipase $n=11$. N. micropogon, $n=6$ for all enzymes 

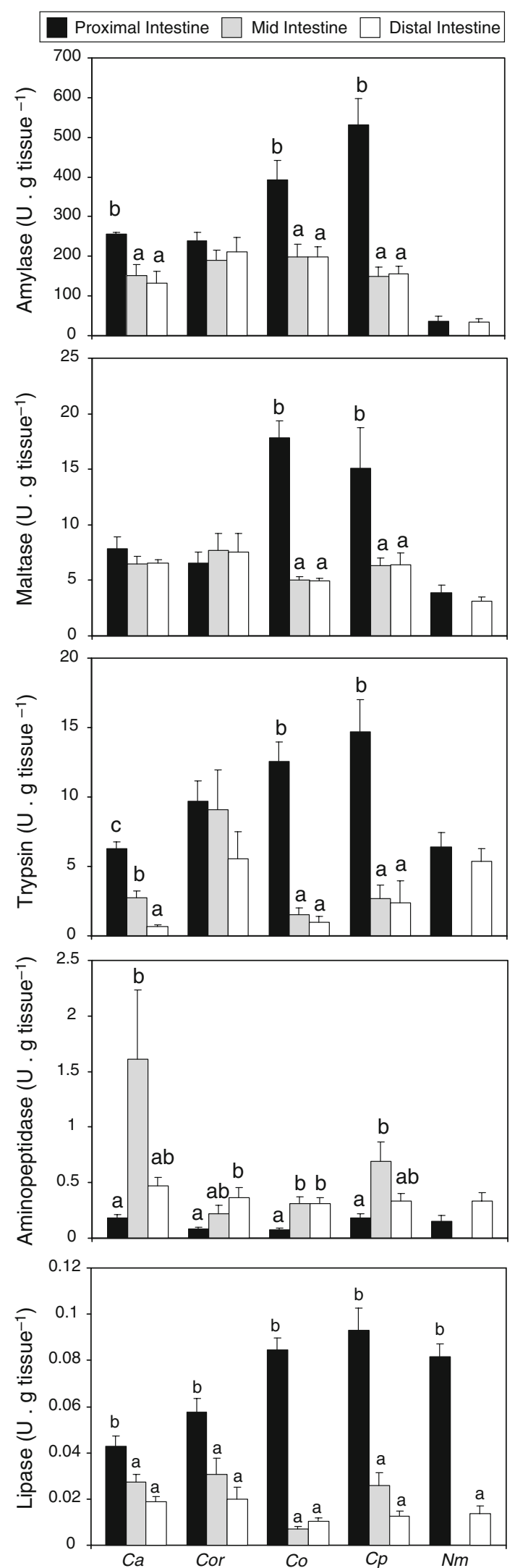

and gut content mass in $C$. ornatum, only the enzyme activities were compared among regions as described above for the other species of Campostoma. Interspecific
Fig. 1 Digestive enzyme activities in three regions of the intestine of five minnow species. Values are mean \pm SEM. Intraspecific comparisons among the gut regions for each enzyme were made with ANOVA followed by Tukey's HSD with a family error rate of $P=0.05$. Bars for a species and enzyme that share a superscript letter are not significantly different. Interspecific comparisons were not performed. ANOVA statistics are summarized in Table 2. Ca, Campostoma anomalum; Cor, C. ornatum; Co, C. oligolepis; $\mathrm{Cp}, \mathrm{C}$. pauciradii; and Nm, Nocomis micropogon

comparisons of the various variables were not made in this study, mainly because the division of the digestive tract was different for $N$. micropogon, making direct comparisons impossible.

\section{Results}

Digestive enzyme activities

With the exception of $C$. ornatum, the Campostoma species showed significant decreases in amylase activity toward the distal intestine (Fig. 1; Table 2). N. micropogon showed no change in its amylase activity between the proximal and distal intestine. The amylase activity of $C$. anomalum, C. ornatum, C. oligolepis, and $C$. pauciradii decreased by $48,12,50$, and $70 \%$, respectively, from proximal to distal portions of the intestine. C. anomalum, C. ornatum, and $N$. micropogon did not show significant changes in maltase activity along the gut, whereas $C$. oligolepis and $C$. pauciradii significantly decreased their maltase activity by 70 and $60 \%$, respectively, in the mid- and distal intestine in comparison to the activities in the proximal intestine.

Similar to amylase, trypsin activity significantly decreased toward the distal intestine in $C$. anomalum, C. oligolepis, and C. pauciradii, but not in C. ornatum (Fig. 1; Table 2). The trypsin activity in the distal intestine of C. anomalum, C. oligolepis, and C. pauciradii was reduced by 90,93 , and $85 \%$, respectively, of its activity in the proximal intestine. Although the change in trypsin activity was not statistically significant in C. ornatum, it decreased by $43 \%$ in the distal intestine in comparison to the proximal intestine. In $N$. micropogon, trypsin activity decreased by only $16 \%$ in the distal intestine when compared to the proximal intestine, which was not a significant difference. In contrast to the other enzymes, aminopeptidase activities increased distally in the alimentary tracts of all four Campostoma species, with $C$. anomalum and $C$. pauciradii showing peaks in the mid intestine. $C$. anomalum had mean aminopeptidase activities that were an order of magnitude higher in the mid than in the proximal intestine, and C. pauciradii increased its aminopeptidase activity nearly fourfold in the mid compared to the proximal intestine. The aminopeptidase activities of $C$. anomalum, $C$. ornatum, C. oligolepis, C. pauciradii, and N. micropogon increased by $2.5,4.5$, 
Table 3 Fluid nutrient concentrations and digesta content masses in different regions of the gut of four species of herbivorous (Campostoma) and carnivorous (Nocomis) minnows

\begin{tabular}{|c|c|c|c|c|}
\hline Gut region & C. anomalum & C. oligolepis & C. pauciradii & N. micropogon \\
\hline \multicolumn{5}{|c|}{ Glucose (mM) } \\
\hline Proximal & $4.19 \pm 0.40$ & $5.49 \pm 0.94^{\mathrm{b}}$ & $6.07 \pm 0.49$ & $3.41 \pm 1.58$ \\
\hline Mid & $3.97 \pm 0.51$ & $2.54 \pm 0.39^{\mathrm{ab}}$ & $3.22 \pm 0.36$ & - \\
\hline \multirow[t]{3}{*}{ Distal } & $5.69 \pm 1.17$ & $2.50 \pm 0.42^{\mathrm{a}}$ & $3.22 \pm 1.88$ & $3.74 \pm 1.82$ \\
\hline & $F_{2,17}=1.47$ & $F_{2,29}=4.05$ & $F_{2,14}=2.43$ & $t=0.14$ \\
\hline & $P=0.26$ & $P=0.03$ & $P=0.13$ & $P=0.89$ \\
\hline \multicolumn{5}{|c|}{ Protein (mg/ml) } \\
\hline Proximal & $14.69 \pm 2.90$ & $30.41 \pm 4.86^{\mathrm{b}}$ & $26.26 \pm 4.81^{\mathrm{b}}$ & $17.60 \pm 5.39$ \\
\hline Mid & $11.12 \pm 1.31$ & $11.73 \pm 1.93^{\mathrm{a}}$ & $13.53 \pm 4.14^{\mathrm{ab}}$ & - \\
\hline \multirow[t]{3}{*}{ Distal } & $11.37 \pm 1.28$ & $12.04 \pm 2.21^{\mathrm{a}}$ & $9.51 \pm 3.66^{\mathrm{a}}$ & $18.86 \pm 5.32$ \\
\hline & $F_{2,17}=1.01$ & $F_{2,29}=10.66$ & $F_{2,14}=4.27$ & $t=0.17$ \\
\hline & $P=0.39$ & $P<0.01$ & $P=0.04$ & $P=0.87$ \\
\hline \multicolumn{5}{|c|}{ Lipid (mg/ml) } \\
\hline Proximal & $14.84 \pm 5.00$ & $40.72 \pm 5.09^{\mathrm{b}}$ & $18.43 \pm 6.04^{\mathrm{b}}$ & $12.71 \pm 2.04$ \\
\hline Mid & $12.78 \pm 2.81$ & $10.96 \pm 1.19^{\mathrm{a}}$ & $10.71 \pm 2.54^{\mathrm{b}}$ & - \\
\hline \multirow[t]{3}{*}{ Distal } & $5.21 \pm 0.34$ & $12.40 \pm 3.86^{\mathrm{a}}$ & $3.40 \pm 2.08^{\mathrm{a}}$ & $8.81 \pm 2.53$ \\
\hline & $F_{2,17}=0.35$ & $F_{2,29}=25.63$ & $F_{2,14}=5.69$ & $t=1.20$ \\
\hline & $P=0.71$ & $P<0.01$ & $P=0.02$ & $P=0.27$ \\
\hline \multicolumn{5}{|c|}{ Gut content mass (GCM/BM) } \\
\hline Proximal & $0.013 \pm 0.002$ & $0.032 \pm 0.004$ & $0.019 \pm 0.003$ & $0.012 \pm 0.002$ \\
\hline Mid & $0.015 \pm 0.006$ & $0.027 \pm 0.002$ & $0.022 \pm 0.004$ & - \\
\hline \multirow[t]{3}{*}{ Distal } & $0.006 \pm 0.001$ & $0.029 \pm 0.003$ & $0.024 \pm 0.007$ & $0.013 \pm 0.003$ \\
\hline & $F_{2,26}=1.22$ & $F_{2,29}=0.86$ & $F_{2,29}=0.29$ & $t=0.37$ \\
\hline & $P=0.31$ & $P=0.43$ & $P=0.75$ & $P=0.72$ \\
\hline
\end{tabular}

Values are mean \pm SEM. Comparisons were made among gut regions for each nutrient class and gut content mass for the Campostoma species with ANOVA followed by Tukey's HSD with a family error rate of $P=0.05$. Nutrient concentrations or gut masses for a particular species that share a superscript letter are not significantly different. Comparisons were made among the two gut regions in $N$. micropogon with $t$-test. Sample sizes (nutrient analyses; gut content mass): C. anomalum (6; 9), C. oligolepis $(10 ; 10)$, C. pauciradii $(5 ; 10)$, and $N$. micropogon (5; 5)

4.0, 2.0, and 2.0 fold, respectively, in the distal intestine in comparison to the proximal intestine, but this increase was only statistically significant in C. ornatum and C. oligolepis. Nonetheless, all five taxa showed increased ability to hydrolyze dipeptides in the mid- and distal intestine in comparison to the proximal intestine.

All five species significantly decreased their lipase activities proximal to distal along the gut (Fig. 1). Individuals of C. anomalum, C. ornatum, C. oligolepis, C. pauciradii, and $N$. micropogon decreased their lipase activities by 56,65 , 88,84 , and $83 \%$, respectively, in the distal intestine compared to the proximal intestine, indicating that their ability to hydrolyze lipids is lower in the distal intestine.

Luminal nutrient concentrations and gut content mass

Campostoma oligolepis and C. pauciradii decreased the glucose concentrations in the fluid of their distal intestine compared to the proximal intestine by 55 and $47 \%$, respectively, but this difference was only statistically significant for C. oligolepis. C. anomalum and $N$. micropogon increased their glucose concentrations by 36 and 10\%, respectively, in the distal intestine (Table 3 ). The protein concentration in the distal digestive fluids of $C$. anomalum, C. oligolepis, and $C$. pauciradii decreased by 23,60 , and $64 \%$, respectively, in comparison to protein concentrations in the proximal gut fluid, but only significantly so for $C$. oligolepis and C. pauciradii; N. micropogon showed a slight, but non-significant increase $(7 \%)$ in protein concentration in the distal intestine (Table 3). All four minnow taxa decreased the lipid concentrations in the gut fluid of the distal intestine in comparison to the proximal intestine, but only significantly so in $C$. oligolepis and $C$. pauciradii. No differences were observed in the RGCM in any gut region in any of the four species (Table 3).

Gastrointestinal fermentation

None of the minnow taxa showed significant changes in SCFA concentrations along the gut, and overall levels of 
Table 4 Total short chain fatty acid concentrations in each gut region of four minnow species

\begin{tabular}{lllll}
\hline Gut region & C. anomalum & C. oligolepis & C. pauciradii & $N$. micropogon \\
\hline Proximal & $3.65 \pm 0.84$ & $6.15 \pm 0.75$ & $4.55 \pm 0.76$ & $6.83 \pm 0.89$ \\
Mid & $4.48 \pm 0.51$ & $9.39 \pm 1.56$ & $4.93 \pm 1.44$ & - \\
Distal & $4.83 \pm 0.77$ & $7.00 \pm 0.82$ & $3.91 \pm 0.62$ & $7.59 \pm 1.72$ \\
& $F_{2,17}=0.71$ & $F_{2,29}=2.31$ & $F_{2,20}=0.26$ & $t=0.39$ \\
& $P=0.51$ & $P=0.12$ & $P=0.77$ & $P=0.71$ \\
\hline
\end{tabular}

Values are $\mathrm{mM}^{-1}$ intestinal fluid, are presented as mean \pm SEM. Comparisons of SCFA concentrations among gut regions for the Campostoma species were made with ANOVA, with differences considered significant at $P=0.05$. SCFA concentrations in the PI and DI of N. micropogon were compared with $t$-test. Sample sizes: C. anomalum (6), C. oligolepis (10), C. pauciradii (7), and $N$. micropogon (5)

fermentation were not concentrated in one gut region (Table 4; Fig. 2). All four minnow species in which I measured SCFA concentrations showed a dominance of acetate over the other SCFA, and the proportion of acetate in comparison to the other SCFA increased distally along the gut. The ratios for acetate:propionate:butyrate in each gut region for the four minnow taxa were as follows: C. anomalum, PI-82:3:2, MI-89:3:1, DI-92:2:0.4; C. oligolepis, PI-64:15:15, MI-74:13:9, DI-76:10:8; C. pauciradii, PI-45:22:22, MI-49:26:9, DI-51:24:11; N. micropogon, PI-42:22:8, DI-54:13:14. Notably, N. micropogon had the highest proportions of isobutyrate and isovalerate (PI-30\%, DI-20\%) in its gut, and these two SCFA were low $(<15 \%)$ in all gut regions of the Campostoma species.

\section{Discussion}

The results of this study essentially support the hypothesis that small herbivorous minnows have intestines that function as PFRs. With few exceptions, the activities of amylase, trypsin, and lipase decreased in the distal region of digestive tract of the Campostoma species. Maltase activities tended to remain the same (C. anomalum, $C$. ornatum, and $N$. micropogon) or to decrease distally in the gut (C. oligolepis and C. pauciradii), concomitant with regional glucose concentrations along the intestines of these species. In contrast, aminopeptidase activities generally increased distally in the alimentary tract. Protein and lipid concentrations decreased in the distal intestine, whereas SCFA and gut content mass were not localized to one gut region, which, along with the unspecialized gut morphology of these minnows (German et al. 2009), suggests that their guts function as PFRs. Differences between the herbivorous species of Campostoma and the carnivorous N. micropogon
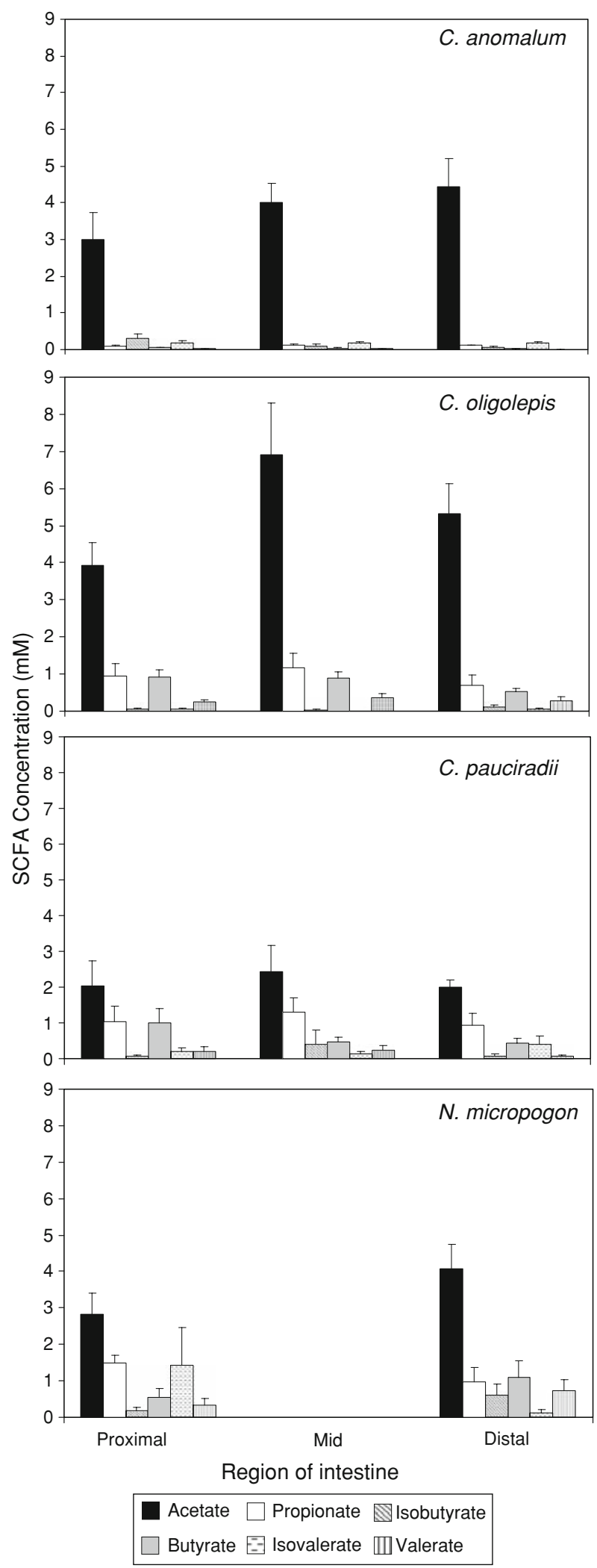

Fig. 2 Concentrations (mM) of short-chain fatty acids (SCFA) acetate, propionate, isobutyrate, butyrate, isovalerate, and valerate among gut regions of four minnow species 
show that the guts of these herbivores and carnivore function in slightly different ways, most likely relating to dietary quality and intake.

Although digestive enzyme activities have been measured along the digestive tracts of numerous wild-caught (e.g., Fish 1960; Hofer 1982; Chakrabarti et al. 1995; Smoot and Findlay 2000; Logothetis et al. 2001; Gawlicka and Horn 2005; Skea et al. 2005, 2007), and cultured fish species (e.g., Chiu and Benitez 1981; Harpaz and Uni 1999; Tengjaroenkul et al. 2000; Hakim et al. 2006, 2007), few have considered these activities in the context of chemical reactor models. Amylase and trypsin activities are known to decrease distally in the intestine of several cyprinid taxa (Hofer and Schiemer 1981; Hofer 1982; Bitterlich 1985; Das and Tripathy 1991; Chakrabarti et al. 1995). Given that amylase and trypsin are pancreatic in origin, and are therefore secreted in the proximal intestine, it makes sense that the activities of these enzymes decrease in the hindgut as their substrates are diminished and the enzymes themselves are broken down or reabsorbed (Hofer 1982; Clements and Raubenheimer 2006). Lipase activity decreases distally in the guts of several cyprinids (Das and Tripathy 1991; Chakrabarti et al. 1995) and other detritivorous fish (e.g., gizzard shad; Smoot and Findlay 2000; Loricariid catfishes; German 2008), most likely for the same reason, as this enzyme is also secreted by the pancreas.

Maltase activities were expected to increase in the midand distal intestine of the minnows. However, two patterns of maltase activities along the digestive tract emerged in this study: one where maltase activities decreased moving distally in the intestine (C. oligolepis and C. pauciradii), and one where maltase activities were relatively similar throughout the gut (C. anomalum, $C$. ornatum, and N. micropogon). Among the Campostoma, these differences fall directly along phylogenetic lines, as the two groups of sister-taxa (C. oligolepis and C. pauciradii vs. C. anomalum and $C$. ornatum) show differing patterns. Sister-taxa similarity in digestive enzyme activities has been observed in prickleback fishes (German et al. 2004), and a similar split relating to laminarinase activity was observed in these same minnow species (German et al. 2009). Exactly why the patterns of maltase activity would differ among these two clades is unknown but may have to do with dietary selection.

The diet of the Campostoma species is best described as "periphyton" or the epilithic algal complex (EAC), which is composed of bacteria, cyanobacteria, filamentous green algae, diatoms, and detritus growing on hard substrates (Hoagland et al. 1982; van Dam et al. 2002; Klock et al. 2007). The EAC can be rich in soluble polysaccharides (Leppard 1995; Wotton 2004; Klock et al. 2007) as well as in lipids (Napolitano et al. 1996) and proteins (Bowen et al. 1995; Wilson et al. 2003; Crossman et al. 2005). Thus, the
EAC can be considerably more nutritious and easier to digest and subsist on than a purely algal diet, and likely would allow a fish to rely on endogenous digestive mechanisms (Crossman et al. 2005) and have a PFR gut.

Measurable glucose in the gut fluid of these fishes illustrates that they are consuming a highly digestible food that is rich in soluble polysaccharides. Other herbivorous fishes that consume macro- and microalgae, which are lower in soluble polysaccharides, have little or no detectable glucose in their digestive tracts (Skea et al. 2005, 2007; German 2008). Given that there is measurable glucose left in the distal intestine of these minnows suggests that some glucose may even escape the gut unabsorbed. Protein is known to be the limiting nutrient for fishes grazing on the EAC (Bowen et al. 1995) and algae (Raubenheimer et al. 2005). Thus, in the context of compartment models of digestion and nutrient targets (Raubenheimer and Simpson 1998), if protein is the limiting nutrient and carbohydrates are overly abundant to these minnows, then perhaps they have optimized intake and retention time to maximize protein digestion and assimilation, even at the cost of losing some glucose in their feces (i.e., "wastage"; Raubenheimer and Simpson 1998; Clements and Raubenheimer 2006). This may be especially true for $C$. anomalum and $C$. ornatum. The patterns of aminopeptidase activity along the gut support this idea, as the activity of this dipeptidase increased distally in the guts of all five minnow taxa. Aminopeptidase indicates the ability of the fish to hydrolyze dipeptides just preceding absorption of amino acids in the gut (Fraisse et al. 1981; Harpaz and Uni 1999). So it seems logical that increasing activities of this enzyme reflect an increased capacity to absorb proteins distally in the intestine. A similar pattern has been observed in tilapia (Harpaz and Uni 1999), which are known to be detritivorous in natural settings, and feed to meet protein requirements (Bowen 1980, 1981; Bowen et al. 1995).

Trypsin activity is generally not different in the guts of Campostoma and Nocomis (German et al. 2009), and in this study, it is apparent that the Campostoma have qualitatively higher aminopeptidase activities than $N$. micropogon. By incorporating intake and retention time, the Campostoma taxa may actually synthesize more of these proteases (German et al. 2009), and therefore, have higher trypsin and aminopeptidase activities on a daily basis than the carnivorous Nocomis (Hofer and Schiemer 1981), showing that these EAC feeders efficiently digest and assimilate protein from their diet.

Some interesting differences were observed in the digestive enzyme activity and luminal nutrient concentration patterns along the intestine between the Campostoma species and $N$. micropogon. Whereas amylase and trypsin activities generally decreased in the distal intestines of the herbivores, these enzyme activities remained constant in the 
proximal and distal intestine of N. micropogon. Furthermore, amylase was noticeably lower in $N$. micropogon, and each of the Campostoma taxa had significantly higher amylase in their gut than N. micropogon (German et al. 2009). Amylase activity has been shown to be higher in herbivorous than in carnivorous fishes (Fernandez et al. 2001; German et al. 2004; Horn et al. 2006), so this finding is not surprising. However, the lack of any patterns of activity of amylase and trypsin, nor in the concentrations of glucose and protein along the $N$. micropogon gut, challenge the PFR model in this species. Their gut is considerably shorter ( $0.86 \times$ their body length) than the guts of the Campostoma species (3.2-5.4× their body length; German et al. 2009), and, because their insect diet is likely higher in protein than an EAC diet, they probably have lower intake than the Campostoma. This is, in fact, predicted by their shorter guts (Sibly and Calow 1986; Horn and Messer 1992), and in further support, $N$. micropogon had lower overall gut content masses than any Campostoma species (German et al. 2009). With lower intake, a higher protein diet, and a shorter gut, $N$. micropogon may have more axial mixing of digesta within their intestine, or at least lower gut motility than the Campostoma. This slowing, or breakdown in PFR function has been observed in the herbivorous prickleback fish Cebidichthys violaceus feeding on a high-protein diet (Fris and Horn 1993), in the omnivorous Girella tricuspidata feeding on a more protein-rich alga (Raubenheimer et al. 2005), and in the halfbeak, Hyporhamphus melanochir, feeding on invertebrates in comparison to when feeding on sea grass (Klumpp and Nichols 1983).

Over the last 20 years it has become increasingly clear that herbivorous fishes do not all function like terrestrial vertebrate herbivores with respect to gastrointestinal fermentation (Choat and Clements 1998; Clements et al. 2009). In fact, many fish taxa categorized as nominally herbivorous (e.g., parrotfishes) include species that consume primarily detritus, which is moderately rich in protein and low in structural polysaccharides, unlike algae and plants (Crossman et al. 2005). Crossman and colleagues illustrated that there is a basic continuum of feeding habits in tropical "herbivorous" fishes, ranging from detritivores with rapid throughput rates and low levels of fermentation in their guts (i.e., guts that function like PFRs), to herbivores with lower throughput rates and high levels of fermentation, primarily localized in the hindgut. Foregut fermentation, which is found in ruminants, kangaroos, and a bird, the hoatzin (Stevens and Hume 1995; Karasov and Hume 1997; Stevens and Hume 1998), is unknown in fishes. The Campostoma showed no localization of SCFAs in the digestive tract, and the overall concentrations of SCFAs were low. For example, the highest SCFA concentrations observed in the mid intestine of $C$. oligolepis (9.39 mM total SCFAs) qualify as low fermentation poten- tial (i.e., $<20 \mathrm{mM}$ ) among fishes (Choat and Clements 1998). The lack of any localized region of fermentation in the minnow guts suggests that, similar to the fellow cyprinids grass carp and common carp (Smith et al. 1996; Stevens and Hume 1998), Campostoma do not rely on gastrointestinal fermentation to meet their daily energy needs. Furthermore, the Campostoma likely consume microbes with their food, which may already be engaged in fermentative digestion of detrital material. Horn and Messer (1992) predicted that fermentation in fishes with PFR intestines would likely come from microbes ingested with their food, rather than endosymbionts per se.

The proportional amount of acetate produced in the minnow guts increases toward the distal intestine. Acetate is produced in higher proportions by microbes digesting more structural polysaccharides (e.g., cellulose), whereas propionate is often produced in higher proportions when soluble polysaccharides are fermented (Bergman 1990). Because the Campostoma taxa are rapidly digesting the soluble component of the EAC in the proximal intestine, as evidenced by higher amylase activities and glucose concentrations in the foregut, this leaves less soluble and more structural elements toward the distal intestine, possibly accounting for the higher proportion of acetate produced there.

Some fishes (Titus and Ahearn 1988; Mountfort et al. 2002), and cyprinids in particular (Smith et al. 1996), are known to be able to absorb and utilize SCFA as a potential energy source, but given the low concentrations of SCFA in Campostoma guts, these by-products of fermentation probably contribute little to their daily energy budgets. Even small $(3 \mathrm{~g})$ detritivorous bullfrog tadpoles, which meet about $20 \%$ of their daily energy needs via gastrointestinal fermentation, have approximately $35 \mathrm{mM}$ SCFA in their guts, mostly concentrated in their hindgut (Pryor and Bjorndal 2005). Additionally, animals can produce "endogenous" acetate by degrading acetyl-CoA in their tissues, and circulating acetate in the blood (Annison and White 1962; Clements et al. 1994); up to $40 \%$ of acetate in sheep blood may be from endogenous production (Annison and White 1962). Thus, it is possible that the low levels of fermentation in the minnow guts, and the low concentrations of acetate in particular, are low enough to allow a diffusion gradient of acetate from the blood stream into the intestinal lumen, leading to low concentrations of acetate in the intestinal fluid. However, explicit investigation of this hypothesis is necessary to test this assertion.

Nocomis micropogon also had low levels of fermentative digestion in its gut. However, this carnivore showed evidence (i.e., higher concentrations of isobutyrate and isovalerate) that amino acids were fermented in its intestine. The diet of N. micropogon is dominated by adult and larval insects, and includes some $(\sim 25 \%)$ algae and detritus 
(Lachner 1950; German et al. 2009). Thus, it is possible that microbes ingested with the algae and detritus ferment amino acids that are not directly absorbed by the fish.

In conclusion, the data gathered on digestive enzyme activities, luminal nutrient concentrations, and gastrointestinal fermentation suggest that herbivorous minnows of the genus Campostoma indeed have guts that function as PFRs as described by Horn and Messer (1992). Because they consume large amounts of a food (EAC) that may be of higher quality than their truly "herbivorous" counterparts that eat macroalgae or plants, they can rely more on endogenous digestive mechanisms. This appears to be common among cyprinids, as none has been reported to possess high concentrations of SCFA in their digestive tracts. The differences in maltase activity among members of the two Campostoma clades warrant further investigation, especially in the context of dietary selectivity. Nonetheless, it is clear that these minnows survive on a diet of EAC organisms and do not use gastrointestinal symbionts to digest algal polysaccharides. Given the important role of Campostoma species in North American freshwater systems, this may have important implications on nutrient cycling and trophodynamics of these habitats, $>45 \%$ of which are severely threatened by human activities (Waters 1995).

The circumstantial nature of this investigation leads to a call for better predictive modeling of fish gut function and more research into fish nutritional ecology; the latter pales in comparison to the nutritional ecology of terrestrial vertebrates (Clements et al. 2009). Better knowledge of food biochemical composition, food selection, and digestive physiology can provide more insight into the variables that offer the most predictive power for modeling fish digestion. For example, how do food biochemical composition, gut capacity, gut transit times, digestive enzyme activities, absorptive efficiency, and algal and plant secondary metabolites interact to affect the digestive process? What defines food quality (e.g., protein content, Neighbors and Horn 1991; food stoichiometry, Mitra and Flynn 2007), and how does this affect diet choice in nature? Knowledge of these processes will allow us to better define fish feeding, digestion, and the ecological roles of fishes in the years to come (Clements et al. 2009).

Acknowledgments I wish to thank David H. Evans, Karen A. Bjorndal, Douglas J. Levey, and Kendall D. Clements for guidance and comments on an earlier version of this manuscript. Jennette Villeda, Ana Ruiz, Brett Nagle, Alfred Thomson, Daniel Neuberger, Jeremy Wright, Ankita Patel, and Stephanie Boyd provided field and laboratory assistance. Handling of fish from capture to euthanization was conducted under approved protocol E006 of the Institutional Animal Care and Use Committee at the University of Florida, which ensures that all research was conducted under the current laws of the United States of America. This project was funded by an American Museum of Natural History Theodore Roosevelt Memorial Grant, a University of Florida Mentoring Opportunity Program Scholarship, a University of Florida Department of Zoology Brian Riewald Memorial Grant, and a National Science Foundation (NSF) GK-12 research stipend (to DPG). Additional funding came from NSF grant IOB-0519579 (D.H. Evans, PI). Lastly, I thank Dr Salvador Contreras-Balderas for help collecting fish in Mexico. Unfortunately, Dr Contreras-Balderas passed away before this article was published. May he rest in peace.

Open Access This article is distributed under the terms of the Creative Commons Attribution Noncommercial License which permits any noncommercial use, distribution, and reproduction in any medium, provided the original author(s) and source are credited.

\section{References}

Annison EF, White RR (1962) Further studies on the entry rates of acetate and glucose in sheep, with special reference to endogenous production of acetate. Biochem J 84:546-552

Bergman E (1990) Energy contributions of volatile fatty acids from the gastrointestinal tract in various species. Physiol Rev 70:567-590

Bitterlich G (1985) Digestive enzyme pattern of two stomachless filter feeders, silver carp, Hypophthalmichthys molitrix Val., and bighead carp, Aristichthys nobilis Rich. J Fish Biol 27:103-112

Bouchard S, Bjorndal K (2005) Microbial fermentation in juvenile and adult pond slider turtles, Trachemys scripta. J Herpetol 39:321-324

Bowen SH (1980) Detrital nonprotein amino acids are the key to rapid growth of tilapia in Lake Valencia, Venezuela. Science 207:1216-1218

Bowen SH (1981) Digestion and assimilation of periphytic detrital aggregate by Tilapia mossambica. Trans Am Fish Soc 110:239245

Bowen SH, Lutz EV, Ahlgren MO (1995) Dietary protein and energy as determinants of food quality: trophic strategies compared. Ecology 76:899-907

Chakrabarti I, Gani MA, Chaki KK, Sur R, Misra KK (1995) Digestive enzymes in 11 freshwater teleost fish species in relation to food habit and niche segregation. Comp Biochem Physiol 112A:167-177

Chiu YN, Benitez LV (1981) Studies on the carbohydrases in the digestive tract of the Milkfish Chanos chanos. Mar Biol 61:247-254

Choat JH, Clements KD (1998) Vertebrate herbivores in marine and terrestrial environments: a nutritional ecology perspective. Annu Rev Ecol Syst 29:375-403

Clements KD, Rees D (1998) Preservation of inherrent contractility in isolated gut segments of herbivorous and carnivorous marine fish. J Comp Physiol B 168:61-72

Clements KD, Raubenheimer D (2006) Feeding and nutrition. In: Evans DH (ed) The physiology of fishes. CRC Press, Boca Raton, pp 47-82

Clements KD, Gleeson V, Slaytor M (1994) Short-chain fatty acid metabolism in temperate marine herbivorous fish. J Comp Physiol B 164:372-377

Clements KD, Raubenheimer D, Choat JH (2009) Nutritional ecology of marine herbivorous fishes: ten years on. Funct Ecol 23:79-92

Cloe WI, Garman G, Stranko S (1995) The potential of the bull chub (Nocomis raneyi) as a predator of the zebra mussel (Dreissena polymorpha) in mid-Atlantic coastal rivers. Am Midl Nat 133:170-176

Crossman DJ, Choat JH, Clements KD (2005) Nutritional ecology of nominally herbivorous fishes on coral reefs. Mar Ecol Prog Ser 296:129-142

Dahlqvist A (1968) Assay of intestinal disacharidases. Anal Biochem 22:99-107

Das KM, Tripathy SD (1991) Studies on the digestive enzymes of grass carp, Ctenopharyngodon idella (Val.). Aquaculture 92:21-32 
Erlanger BF, Kokowsky N, Cohen W (1961) The preparation and properties of two new chromogenic substrates of trypsin. Arch Biochem Biophys 95:271-278

Evans HE, Deubler EE Jr (1955) Pharyngeal tooth replacement in Semotilus atromaculatus and Clinostomus elongatus, two species of cyprinid fishes. Copeia 1955:31-41

Evans-White M, Dodds WK, Whiles M (2003) Ecosystem significance of crayfishes and stonerollers in a prairie stream: functional differences between co-occurring omnivores. J North Am Benthol Soc 22:423-441

Fernandez I, Moyano FJ, Diaz M, Martinez T (2001) Characterization of $\alpha$-amylase activity in five species of Mediterranean sparid fishes (Sparidae, Teleostei). J Exp Mar Biol Ecol 262:1-12

Fish GR (1960) The comparative activity of some digestive enzymes in the alimentary canal of Tilapia and Perch. Hydrobiologia 15:161-178

Fowler JF, Taber CA (1985) Food habits and feeding periodicity in two sympatric stonerollers (Cyprinidae). Am Midl Nat $135: 217-224$

Fraisse M, Woo NYS, Noaillac-Depeyre J, Murat JC (1981) Distribution pattern of digestive enzyme activities in intestine of the catfish (Ameiurus nebulosus L.) and of the carp (Cyprinus carpio L.). Comp Biochem Physiol 70A:443-446

Fris MB, Horn MH (1993) Effects of diets of different protein content on food consumption, gut retention, protein conversion, and growth of Cebidichthys violaceus (Girard), an herbivorous fish of temperate zone marine waters. J Exp Mar Biol Ecol 166:185-202

Gawlicka A, Horn MH (2005) Storage and absorption in the digestive system of carnivorous and herbivorous prickleback fishes (Teleostei: Stichaeidae): ontogenetic, dietary, and phylogenetic effects. Physiol Biochem Zool 78:879-892

Gawlicka A, Parent B, Horn MH, Ross N, Opstad I, Torrissen OJ (2000) Activity of digestive enzymes in yolk-sac larvae of Atlantic halibut (Hippoglossus hippoglossus): indication of readiness for first feeding. Aquaculture 184:303-314

Gelwick F, Matthews W (1992) Effects of an algivorous minnow on temperate stream ecosystem properties. Ecology 73:1630-1645

Gelwick F, Matthews W (1997) Effects of algivorous minnows (Campostoma) on spatial and temporal heterogeneity of stream periphyton. Oecologia 112:386-392

German DP (2008) Beavers of the fish world: can wood-eating catfishes actually digest wood? A nutritional physiology approach. $\mathrm{Ph} . D$. dissertation, University of Florida, Gainesville

German DP, Horn MH, Gawlicka A (2004) Digestive enzyme activities in herbivorous and carnivorous prickleback fishes (Teleostei: Stichaeidae): ontogenetic, dietary, and phylogenetic effects. Physiol Biochem Zool 77:789-804

German DP, Nagle B, Villeda JM, Ruiz AM, Thomson AW, ContrerasBalderas S, Evans DH (2009) Evolution of herbivory in a carnivorous clade of minnows (Teleostei: Cyprinidae): effects on gut size and digestive physiology. Physiol Biochem Zool (in press)

Hakim Y, Uni Z, Hulata G, Harpaz S (2006) Relationship between intestinal brush border enzymatic activity and growth rate in tilapias fed diets containing $30 \%$ or $48 \%$ protein. Aquaculture 257:420-428

Hakim Y, Rowland SJ, Guy JA, Mifsud C, Uni Z, Harpaz S (2007) Effects of genetic strain and holding facility on the characteristics of alkaline phosphatase and brush border enzymes in silver perch (Bidyanus bidyanus). Aquac Res 38:361-372

Harpaz S, Uni Z (1999) Activity of intestinal mucosal brush border membrane enzymes in relation to the feeding habits of three aquaculture fish species. Comp Biochem Physiol A Mol Integr Physiol 124:155-160

Hoagland K, Roemer S, Rosowski J (1982) Colonization and community structure of two periphyton assemblages, with emphasis on the diatoms (Bacillariophyceae). Am J Bot 69:188-213
Hofer R (1982) Protein digestion and proteolytic activity in the digestive tract of an omnivorous cyprinid. Comp Biochem Physiol 72A:55-63

Hofer R, Schiemer F (1981) Proteolytic activity in the digestive tract of several species of fish with different feeding habits. Oecologia 48:342-345

Horn MH (1989) Biology of marine herbivorous fishes. Oceanogr Mar Biol Annu Rev 27:167-272

Horn MH, Messer KS (1992) Fish guts as chemical reactors: a model for the alimentary canals of marine herbivorous fishes. Mar Biol 113:527-535

Horn MH, Gawlicka A, German DP, Logothetis EA, Cavanagh JW, Boyle KS (2006) Structure and function of the stomachless digestive system in three related species of New World silverside fishes (Atherinopsidae) representing herbivory, omnivory, and carnivory. Mar Biol 149:1237-1245

Iijima N, Tanaka S, Ota Y (1998) Purification and characterization of bile salt-activated lipase from the hepatopancreas of red seabream, Pagrus major. Fish Physiol Biochem 18:59-69

Jumars PA (2000) Animal guts as nonideal chemical reactors: partial mixing and axial variation in absorption kinetics. Am Nat 155:544-555

Karasov WH, Hume ID (1997) Vertebrate gastrointestinal system. In: Dantzler WH (ed) Handbook of comparative physiology. American Physiological Society, Bethesda, pp 407-480

Karasov WH, Martínez del Rio C (2007) Physiological ecology: how animals process energy, nutrients, and toxins. Princeton University Press, Princeton

Klock JH, Wieland A, Seifert R, Michaelis W (2007) Extracellular polymeric substances (EPS) from cyanobacterial mats: characterisation and isolation method optimisation. Mar Biol 152:10771085

Klumpp DW, Nichols PD (1983) Study of food-chains in seagrass communities. 4. Nutrition of the Southern Sea garfish Hyporhamphus melanochir - gut passage rate and daily consumption of 2 food types and assimilation of seagrass components. Mar Ecol Prog Ser 12:207-216

Kraatz WC (1924) The intestine of the minnow Campostoma anomalum (Rafinesque), with special reference to the development of its coiling. Ohio J Sci 24:265-298

Lachner E (1950) The comparative food habits of the cyprinid fishes Nocomis biguttatus and Nocomis micropogon in western New York. J Wash Acad Sci 40:229-236

Leppard GG (1995) The characterization of algal and microbial mucilages and their aggregates in aquatic ecosystems. Sci Total Environ 165:103-131

Logothetis EA, Horn MH, Dickson KA (2001) Gut morphology and function in Atherinops affinis (Teleostei: Atherinopsidae), a stomachless omnivore feeding on macroalgae. J Fish Biol 59:12981312

Marsh JB, Weinstein DB (1966) Simple charring method for the determination of lipids. J Lipid Res 7:574-576

Mayer L, Schick L, Self R, Jumars PA, Findlay R, Chen Z, Sampson S (1997) Digestive environments of benthic macroinvertebrate guts: enzymes, surfactants and dissolved organic matter. J Mar Res 55:785-812

Mitra A, Flynn K (2007) Importance of interactions between food quality, quantity, and gut transit time on consumer feeding, growth, and trophic dynamics. Am Nat 169:632-646

Mountfort D, Campbell J, Clements KD (2002) Hindgut fermentation in three species of marine herbivorous fish. Appl Environ Microbiol 68:1374-1380

Napolitano GE, Shantha NC, HIll WR, Luttrella AE (1996) Lipid and fatty acid compositions of stream periphyton and stoneroller minnows (Campostoma anomalum): trophic and environmental implications. Arch Hydrobiol 137:211-225 
Neighbors MA, Horn MH (1991) Nutritional quality of macrophytes eaten and not eaten by two temperate-zone herbivorous fishes: a multivariate comparison. Mar Biol 108:471-476

Nelson N (1944) A photometric adaptation of the Somogyi method for the determination of glucose. J Biol Chem 153:375-380

Parra R (1978) Comparison of foregut and hindgut fermentation in herbivores. In: Montgomery GG (ed) The ecology of arboreal folivores. Smithsonian Institution, Washington D.C., pp 205-229

Penry DL, Jumars PA (1987) Modeling animal guts as chemical reactors. Am Nat 129:69-96

Power M, Matthews W, Stewart A (1985) Grazing minnows, piscivorous bass, and stream algae: dynamics of a strong interaction. Ecology 66:1448-1456

Power M, Stewart A, Matthews W (1988) Grazer control of algae in an Ozark Mountain stream: effects of short-term exclusion. Ecology 69:1894-1898

Preiser H, Schmitz J, Maestracci D, Crane RK (1975) Modification of an assay for trypsin and its application for the estimation of enteropeptidase. Clin Chim Acta 59:169-175

Pryor GS, Bjorndal K (2005) Symbiotic fermentation, digesta passage, and gastrointestinal morphology in bullfrog tadpoles (Rana catesbeiana). Physiol Biochem Zool 78:201-215

Pryor GS, German DP, Bjorndal K (2006) Gastrointestinal fermentation in greater sirens (Siren lacertina). J Herpetol 40:112-117

Raubenheimer D, Simpson S (1998) Nutrient transfer functions: the site of integration between feeding behaviour and nutritional physiology. Chemoecology 8:61-68

Raubenheimer D, Zemke-White WL, Phillips RJ, Clements KD (2005) Algal macronutrients and food selectivity by the omnivorous marine fish Girella tricuspidata. Ecology 86:2601-2610

Roncari G, Zuber H (1969) Thermophilic aminopeptidases from Bacillus stearothermophilus. I. Isolation, specificity, and general properties of the thermostable aminopeptidase I. Int J Protein Res $1: 45-61$

Seeto G, Veivers P, Clements KD, Slaytor M (1996) Carbohydrate utilisation by microbial symbionts in the marine herbivorous fishes Odax cyanomelas and Crinodus lophodon. J Comp Physiol B 165:571-579

Sibly RM, Calow P (1986) Physiological ecology of animals, an evolutionary approach. Blackwell Scientific Publications, Oxford

Skea G, Mountfort D, Clements KD (2005) Gut carbohydrases from the New Zealand marine herbivorous fishes Kyphosus sydneyanus (Kyphosidae), Aplodactylus arctidens (Aplodactylidae), and Odax pullus (Labridae). Comp Biochem Physiol B Biochem Mol Biol 140:259-269
Skea G, Mountfort D, Clements KD (2007) Contrasting digestive strategies in four New Zealand herbivorous fishes as reflected by carbohydrase activity profiles. Comp Biochem Physiol B Biochem Mol Biol 146:63-70

Smith P, Krohn R, Hermanson G, Mallia A, Gartner F, Provenzano M, Fujimoto E, Goeke N, Olson B, Klenk D (1985) Measurement of protein using bicinchoninic acid. Anal Biochem 150:76-85

Smith T, Wahl D, Mackie R (1996) Volatile fatty acids and anaerobic fermentation in temperate piscivorous and omnivorous freshwater fish. J Fish Biol 48:829-841

Smoot JC, Findlay RH (2000) Digestive enzyme and gut surfactant activity of detrivorous gizzard shad (Dorosoma cepedianum). Can J Fish Aquat Sci 57:1113-1119

Somogyi M (1952) Notes on sugar determination. J Biol Chem 195:19-23

Stevens CE, Hume ID (1995) Comparative physiology of the vertebrate digestive system. Press Syndicate of the University of Cambridge, Melbourne

Stevens CE, Hume ID (1998) Contributions of Microbes in vertebrate gastrointestinal tract to production and conservation of nutrients. Physiol Rev 78:393-427

Tengjaroenkul B, Smith B, Caceci T, Smith SA (2000) Distribution of intestinal enzyme activities along the intestinal tract of cultured Nile tilapia, Oreochromis niloticus L. Aquaculture 182:317-327

Titus E, Ahearn GA (1988) Short-chain fatty acid transport in the intestine of a herbivorous teleost. J Exp Biol 135:77-94

van Dam A, Beveridge M, Azim M, Verdegem M (2002) The potential of fish production based on periphyton. Rev Fish Biol Fish 12:1-31

Waters T (1995) Sediment in streams: sources, biological effects and control. American Fisheries Society Monograph 7, American Fisheries Society, Bethesda

Whelan C, Brown J, Schmidt K, Steele B, Willson M (2000) Linking consumer-resource theory and digestive physiology: application to diet shifts. Evol Ecol Res 2:911-934

Wilson SK, Bellwood DR, Choat JH, Furnas MJ (2003) Detritus in the epilithic algal matrix and its use by coral reef fishes. Oceanogr Mar Biol Annu Rev 41:279-309

Wotton RS (2004) The ubiquity and many roles of exopolymers (EPS) in aquatic systems. Sci Mar 68(Suppl 1):13-21

Xie P (1999) Gut contents of silver carp, Hypophthalmichthys molitrix, and the disruption of a centric diatom, Cyclotella, on passage through the esophagus and intestine. Aquaculture 180:295-305

Xie P (2001) Gut contents of bighead carp Aristichthys nobilis and the processing and digestion of algal cells in the alimentary canal. Aquaculture 195:149-161 